\title{
Urban social security survey
}

\author{
Nadezhda Samoylova ${ }^{1,2, *}$, and Alireza Majorzadehzahiri ${ }^{1}$ \\ ${ }^{1}$ Moscow State University of Civil Engineering, 26, Yaroslavskoye shosse, 129337, Moscow, Russia \\ ${ }^{2}$ Russian Academy of Architecture and Building Sciences, 24, Bolshaya Dmitrovka str., 107031, \\ Moscow, Russia
}

\begin{abstract}
The article is devoted to security topics, which is one of the key requirements for improving the quality of life. The article presents the results of a study aimed at improving the safety of people in the area of the largest cities. Questionnaires were prepared and data were collected among residents of the study area on identified security problems as a result of field observations of the vicinity of Tehran (Iran). The study area is Lashkar district in Tehran 8 and east of Tehran where security is very low and the environment is relatively worn and width. The method of this research is descriptive-research. For the purpose of analyzing and assessing the security at the neighborhood level, a set of indicators are used, such as quality of passages, lighting, texture compaction, openness and closure of space, physical form. The following tables are presented in the article: Types of Security, The four theories of crime and violence in urban space, in the context of Swat Lashkar District. The study presented specific proposals (Solutions and Suggestions to create security in the Lashkar neighborhood) for measures of urban planning policy of the study area in Iran.
\end{abstract}

\section{Introduction}

A city is a place of residence, commuting, work, leisure and a place to live and to live, but of course, it must also be a place to live. Therefore, a mechanism must be devised so that people can live in comfortable cities. Living comfortably requires many different mechanisms and means of security. That is, the city must be safe so that anyone, woman or man or child, can travel, park and enjoy the park, street and neighborhood at any time of the day and night without any risk or danger. To think, to write, to choose his discipline according to his abilities and interest, and then to work on his experience, expertise, knowledge, and abilities, without having to pay a stone for his life, economic capital, Human, social and cultural. As well as the need to take into account the interests of other interested participants in the urban planning process (all forms of business, including social, without obtaining only environmental profit, exercising powers of all levels of government and respecting public interests) $[1,2]$.

\footnotetext{
*Corresponding author: grado@mgsu.ru
} 


\section{Expressing the problem}

Security is one of the most important issues to be addressed in urban spaces. Because today's urban spaces are a component of what happens Urban carpentry is a consequence of no security in the city, so it is necessary to examine the qualitative aspects of security both physically and socially in urban spaces. The security is important for the new approaches of city planning thus the security and safeness of the city is needed (Crime Information Analysis Centre, 2000) the way of the research have also the approaches with the documents and analysis, that can be used in the available source; supervision of the environment. The presence of security in urban spaces creates a sense of belonging in the inhabitants of that space. Also, given the complex structure of cities, we need a model that can be used in new urban planning. In fact, this model scientific systematization of the interconnected elements of the territory for the formation of a system of urban planning regulation of the living environment. An information model of the territorial object was formed. This model is a rethinking of cybernetics as applied to urban studies to create selforganized complex systems in the form of various urbanized territories, taking into account the ever-growing need to find a compromise between all interested participants in urban planning regarding the quality and safety of their living environment. The feeling of vitality will create a comfortable environment for the inhabitants and people will be present in the space and the presence of people in the urban spaces will increase security and people will easily walk in the streets. The geographical location of District 8 of Tehran in terms of location and low prices and affordable housing has made people with disabilities and people from all walks of life to migrate to this place and because of different cultures of people, we are faced with reduced security [3].

\section{Research Methods}

The choice of research method is closely related to the purpose and nature of the subject under study and its facilities. Therefore, with regard to the defined purpose, a descriptiveanalytical method is used and to gather information initially library studies And field observations. Then tools such as questionnaires and interviews with residents and authorities were used, and finally, the SWOT model was used for analysis and the necessary strategies and policies were selected. Also in this research 3D analysis, spatial and situational analysis in GIS software were used. As a result of the study using the descriptive-analytical method, problem areas of the territory were found and visualized in the ArcGIS program (https://www.esri.com/ar-sa/home). A continuation of the Qualitative Study of Social Security in Cities will be a practical study of the identified relevant safety factors in these specific areas using a computer program Decision Support System - DSS (https://new.fips.ru/registers-doc-view/fips_servlet?DB=EVM\&DocNumber=2019667346 \&TypeFile=html). A separate managerial task is the implementation of measures to engage real specific local residents in the identified areas and people using this urban area in different spatially temporary periods $[4,5,6,7]$.

\section{Theoretical Foundations}

\subsection{Security}

The concept of security refers to defending or protecting yourself, your family, your friends, and your possessions. The concept of security in the urban space is on the one hand 
linked to crime and on the other to the concept of crime. It should also distinguish between fear and danger or a sense of security and security (table 1). It is important to scientifically understand the effects of crime, that is, the fear of a crime as much as it is itself, the statistical risks of the crime. Reacting to the fear of being victimized causes many people to avoid risks or at least reduce their exposure, which can lead to people not only being in a particular place but also in a particular place, Make more public spaces [8].

Table 1. Types of Security.

\begin{tabular}{|c|c|c|c|c|}
\hline Title & $\begin{array}{c}\text { Security } \\
\text { reference }\end{array}$ & Values at risk & $\begin{array}{c}\text { Sources of } \\
\text { threat }\end{array}$ & $\begin{array}{c}\text { The shape of the } \\
\text { threat }\end{array}$ \\
\hline $\begin{array}{c}\text { National } \\
\text { Security }\end{array}$ & Country or regime & $\begin{array}{c}\text { Independence of } \\
\text { national } \\
\text { sovereignty }\end{array}$ & $\begin{array}{c}\text { Countries } \\
\text { and sub } \\
\text { actors }\end{array}$ & Military invasion \\
\hline $\begin{array}{c}\text { Human } \\
\text { security }\end{array}$ & People, humanity & $\begin{array}{c}\text { Survival and } \\
\text { quality of life }\end{array}$ & $\begin{array}{c}\text { Countries } \\
\text { and disasters }\end{array}$ & $\begin{array}{c}\text { Murder, war, } \\
\text { poverty, crime, } \\
\text { and crime }\end{array}$ \\
\hline $\begin{array}{c}\text { Environmental } \\
\text { security }\end{array}$ & ecosystem & Survival of Life & Humanity & $\begin{array}{c}\text { Pollution, earth } \\
\text { heat, } \\
\text { environmental } \\
\text { degradation }\end{array}$ \\
\hline $\begin{array}{c}\text { Social } \\
\text { Security }\end{array}$ & $\begin{array}{c}\text { Nations, social } \\
\text { groups }\end{array}$ & $\begin{array}{c}\text { Identity Social } \\
\text { unity, norms }\end{array}$ & $\begin{array}{c}\text { Countries } \\
\text { alien cultures }\end{array}$ & $\begin{array}{c}\text { Ethnic cleansing, } \\
\text { genocide } \\
\text { segregation }\end{array}$ \\
\hline
\end{tabular}

\subsection{Social Security Views}

Various theories and opinions on urban security have been put forward, the most important of which are summarized in the table below $[9,10,11,12]$.

\subsection{Identity}

Identity is one of the most important and fundamental issues of human knowledge that many scholars and thinkers have dealt with throughout history. " Certain culture has defined the word identity: What causes a person to be identified. That is, what distinguishes one person from another. It comes from the natural need for human beings to be identified and introduced to the "who's" of meaning, to something or somewhere. This feeling of belonging is an inherent need in every person. In other words, identity is a definition that the individual makes of himself or herself and answers questions such as what I am and what I want, and through which he gives dimensions of his personality, a kind of harmony and psychological coherence. And behavior takes place in time and place. The most important function of identity is to create continuity and identity. There are two elements involved in the realization of this, which are our definition of ourselves and others [13].

\subsection{Crime}

Urban offenses are crimes that occur in the urban environment. The urban environment is the geographical and social concept of the city; in addition to the suburbs, it also includes persons who are informally settled on the outskirts of cities. Concerning the criterion of urban differentiation, some researchers have proposed three important criteria of size, wetness, and variety (table 2). Size is important because as the population grows, people come into contact with each other who are not interdependent and are strangers to one another. This leads to the formation of different classes, socially, among the people. 
Concentration is itself a crime that is not found in non-urban areas. Diversity is also decisive in that people with different cultural, economic, ethical, and other characteristics live together because all these factors and the difference or discrimination in having these characteristics provide the grounds for the crime itself. It makes it impossible to imagine committing them in the rural environment [14].

Table 2. The four theories of crime and violence in urban space.

\begin{tabular}{|c|c|c|c|}
\hline & $\begin{array}{c}\text { Space / Sovereignty } \\
\text { Control }\end{array}$ & Supervision & Activity \\
\hline Jane Jacobs & $\begin{array}{l}\text { Distinguish between } \\
\text { public and private }\end{array}$ & $\begin{array}{l}\text { The need for watchful } \\
\text { eyes by natural owners, } \\
\text { both residents, and } \\
\text { users can be reinforced } \\
\text { by the variety of } \\
\text { activities and functions } \\
\text { that attract people. }\end{array}$ & $\begin{array}{l}\text { Neighborhood } \\
\text { activities on the street } \\
\text { should provide } \\
\text { continuous followers to } \\
\text { strengthen the } \\
\text { discussion of } \\
\text { oversight. }\end{array}$ \\
\hline $\begin{array}{c}\text { Oscar } \\
\text { Newman }\end{array}$ & $\begin{array}{l}\text { The physical environment } \\
\text { must-have characteristics } \\
\text { such as symbolic } \\
\text { mechanisms, boundaries, } \\
\text { and hierarchies defined } \\
\text { from the private to the } \\
\text { public, in order to } \\
\text { understand and understand } \\
\text { different areas. }\end{array}$ & $\begin{array}{l}\text { Building physical } \\
\text { capacity - Monitoring } \\
\text { for residents and other } \\
\text { entities is possible }\end{array}$ & $\begin{array}{l}\text { Contrary to the theory } \\
\text { that the presence of } \\
\text { more activities and } \\
\text { especially the presence } \\
\text { of commercial } \\
\text { activities reduces the } \\
\text { crime rate. }\end{array}$ \\
\hline $\begin{array}{c}\text { Institute } \\
\text { Crime } \\
\text { Prevention } \\
\text { Through } \\
\text { Environmental } \\
\text { Design } \\
\text { (CPTED) }\end{array}$ & $\begin{array}{l}\text { Controlling natural access } \\
\text { to reduce access to crime; } \\
\text { using physical blockages } \\
\text { that increase residents' } \\
\text { heart and sense of } \\
\text { ownership }\end{array}$ & $\begin{array}{l}\text { Natural supervision as } \\
\text { a normal result of the } \\
\text { use of property }\end{array}$ & $\begin{array}{l}\text { Emphasis is on } \\
\text { reducing activity } \\
\text { through movement } \\
\text { and, consequently, } \\
\text { reducing activity } \\
\text { levels. }\end{array}$ \\
\hline $\begin{array}{l}\text { Professor Bill } \\
\text { Hillier }\end{array}$ & $\begin{array}{l}\text { Spaces integrated with } \\
\text { other spaces encourage } \\
\text { pedestrians to move } \\
\text { around and watch in those } \\
\text { spaces. }\end{array}$ & $\begin{array}{l}\text { Monitoring is provided } \\
\text { by people moving } \\
\text { through space. }\end{array}$ & $\begin{array}{l}\text { By integrating space } \\
\text { and traffic paths, one } \\
\text { can define } \\
\text { interconnected spaces } \\
\text { that look secure. }\end{array}$ \\
\hline
\end{tabular}

\subsection{The description and the meaning of the function of CPTED}

This function can be design usefully and the best use of all elements existing in unnatural (artificial) environments for decreasing the city crimes which directly or un directly have a great effect on increasing the quality of life, in satisfying the citizens, improvement in lifestyle (Timothy, 2000). Society center of crime (NICP 2006), this function has been designed and used in making life better, for decreasing or lowering the crimes and improve life. The international committee Crime Prevention Through Environmental Design (CPTED, fig.1) has used this process for decreasing and preventing crimes. The National organization prevention of crime (NCPC 2000). This committee has also used this area skillfully which can decrease the potential crimes. Tim Crow, (manager department international prevention of crimes has used the design of the environment). This project has been known as the security way that predicts the action from the city design and program for decreasing the problem of offense and crimes [3]. 


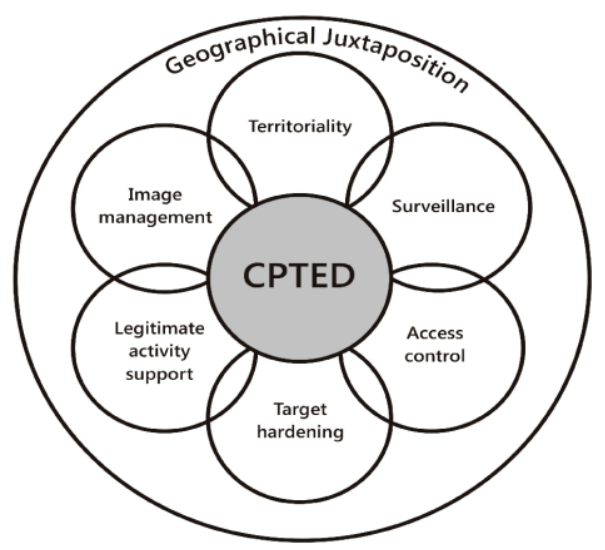

Fig. 1. Crime Prevention Through Environmental Design (CPTED) concepts.

\section{Study area}

District 8 of Tehran, formed by the early core of Nizam Abad, is located in District 8 of Lashkar. District 8 of Tehran Municipality is located in the east with an area of 1339 hectares, between two east-west axes of Tehran (Damavand and Resalat St). District 8 of Tehran Municipality is the entrance gate east of Tehran District 8 is one of the middle-class districts of Tehran and the new middle class, including government employees, technicians, and assistants as well as craftsmen, have chosen the area for their residency. But Zone 3 Zone 8 differs substantially in the placement of people with different jobs, Zone 3 is a lowmiddle-class area and attracts most technicians and drivers. According to the demographic data of the Statistical Center in 2018, Lashkar district has a population of 48047, of which 23976 are men and 24071 are women. The sex ratio is about 103 for the Lashkar neighborhood.

\section{Analysis}

\subsection{Satisfaction and a sense of belonging}

Most of the respondents were less satisfied with the neighborhood and most of the residents did not feel the sense of belonging to the environment and only 14 out of 100 respondents were satisfied and this indicates that there are many problems in the neighborhood (fig. 2).

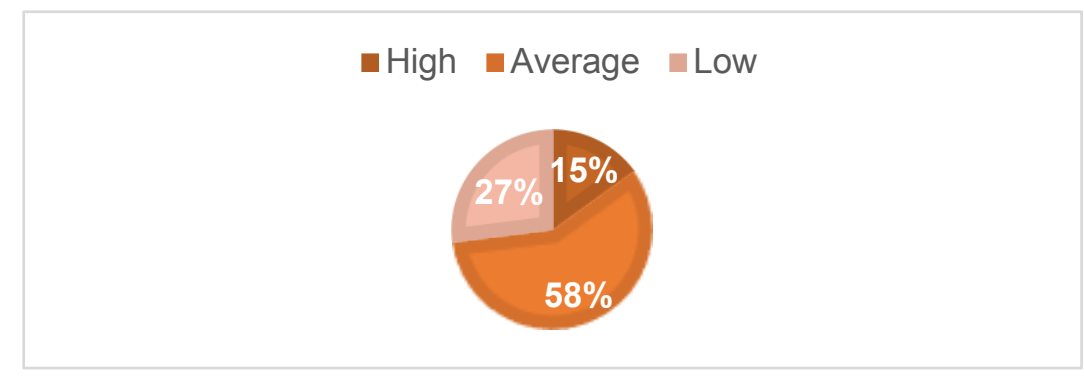

Fig. 2. Satisfaction and a sense of belonging. 


\subsection{Security}

According to people's responses, because of reduced security at night, the presence of women and adolescents at night alone in certain conditions is associated with intimidation and fear. Traffic is diminished in the neighborhood when the weather is dark, with the majority of vulnerable adolescents and youth (fig. 3).

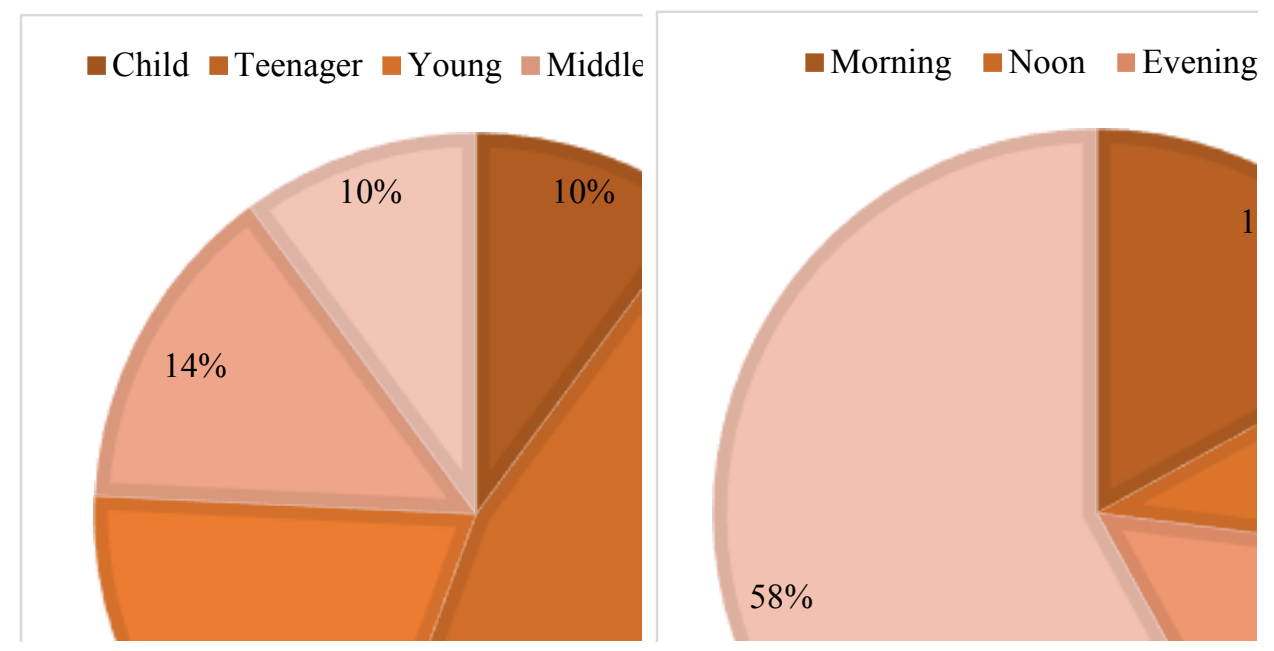

Fig. 3. Age Groups at Risk. Hours of Traffic Reduction in the Are.

\subsection{Density and number of floors}

Three-dimensional analysis of this neighborhood in GIS software was unfortunately observed due to the compactness of the city form and a large number of buildings and the height and number of floors in the area that do not fit the shape and form of streets and alleys and also the low pedestrian width (fig. 4). Inadequate lighting and pedestrian access in these passages have created unsafe areas in the neighborhood due to non-compliance with urban planning laws.

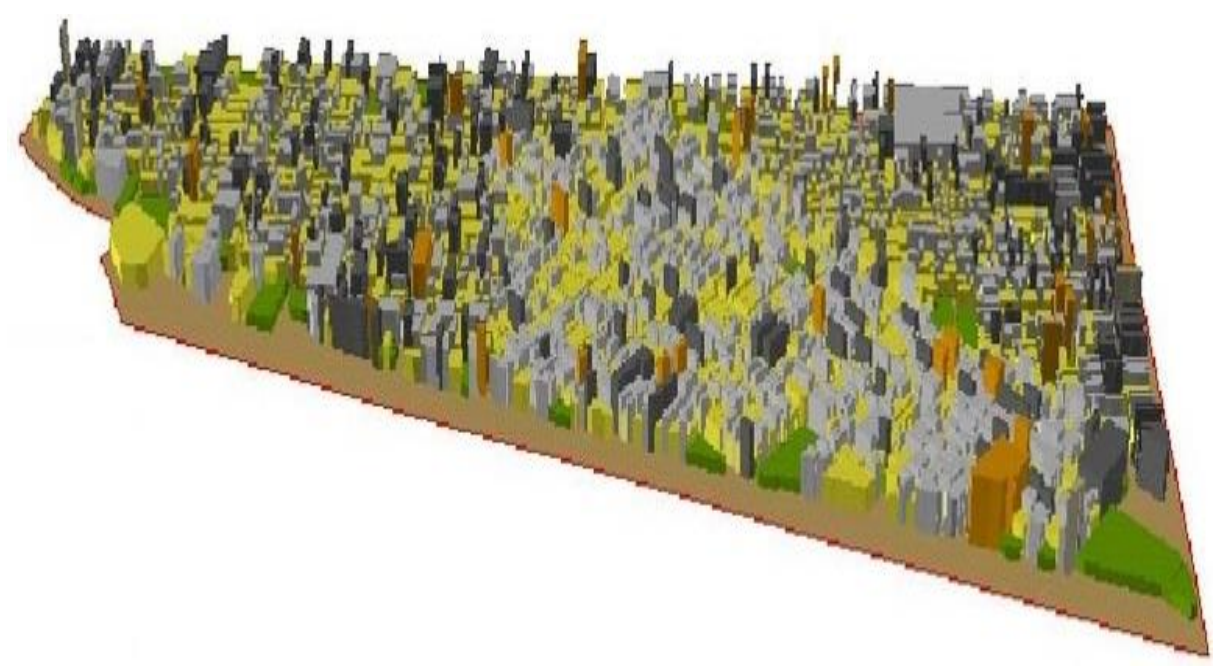

Fig. 4. Analysis of density and number of floors. 


\subsection{Swat}

According to the results of the questionnaire and their analysis, the table is done swot (table 3). The following is provided.

Table 3. Swat Lashkar District.

\begin{tabular}{|c|c|c|c|c|}
\hline Components & Strengths & Weak points & $\begin{array}{c}\text { The } \\
\text { opportunity }\end{array}$ & Threat \\
\hline $\begin{array}{l}\text { Geographical a } \\
\text { nd social }\end{array}$ & $\begin{array}{l}\text { Increase the } \\
\text { literacy of } \\
\text { neighborho } \\
\text { od residents }\end{array}$ & $\begin{array}{l}\text { Existence of social } \\
\text { anomalies }\end{array}$ & & \\
\hline Economical & & $\begin{array}{l}\text { Residents' financial } \\
\text { weakness }\end{array}$ & & \\
\hline Physical & & & $\begin{array}{c}\text { Convert } \\
\text { wreckage and } \\
\text { degraded } \\
\text { landfills into } \\
\text { mixed landfills. }\end{array}$ & $\begin{array}{c}\text { Dangerous } \\
\text { neighborhoods } \\
\text { in the } \\
\text { neighborhood } \\
\text { and terrorizing } \\
\text { neighborhoods }\end{array}$ \\
\hline Infrastructure & & $\begin{array}{l}\text { Park motor vehicles on } \\
\text { the sidewalks. } \\
\text { Improper network } \\
\text { access } \\
\text { The problem was water } \\
\text { and sewage in the } \\
\text { streets } \\
\end{array}$ & & \\
\hline $\begin{array}{c}\text { Environmental } \\
\text { quality }\end{array}$ & & $\begin{array}{l}\text { There are uses such as } \\
\text { repair shop and oil } \\
\text { change that lead to } \\
\text { contamination. } \\
\text { Lack of green space at } \\
\text { the neighborhood level }\end{array}$ & & \\
\hline Managerial & & $\begin{array}{c}\text { There was no detailed } \\
\text { plan for } \\
\text { the neighborhood }\end{array}$ & & \\
\hline
\end{tabular}

\subsection{Insecure neighborhood space}

In this research In this study, according to the results of the questionnaire and field surveys based on CPTED criteria, unsafe areas of this area were identified in GIS software as shown in fig. 5.

\section{Strategies}

According to current neighborhood surveys, strategies we can use to improve the quality of life and urban security in the neighborhood include: 


\subsection{Environmental strategies}

Protecting the values of the natural environment in the neighborhood with the potential for increased productivity such as accommodation in tourism and catering activities.

Managing water and energy consumption, controlling human development, using new technologies, and preventing the proliferation of industrial and residential applications in the neighborhood.

Taking advantage of the city edge in a proposal for the development of recreational, sports and tourism facilities.

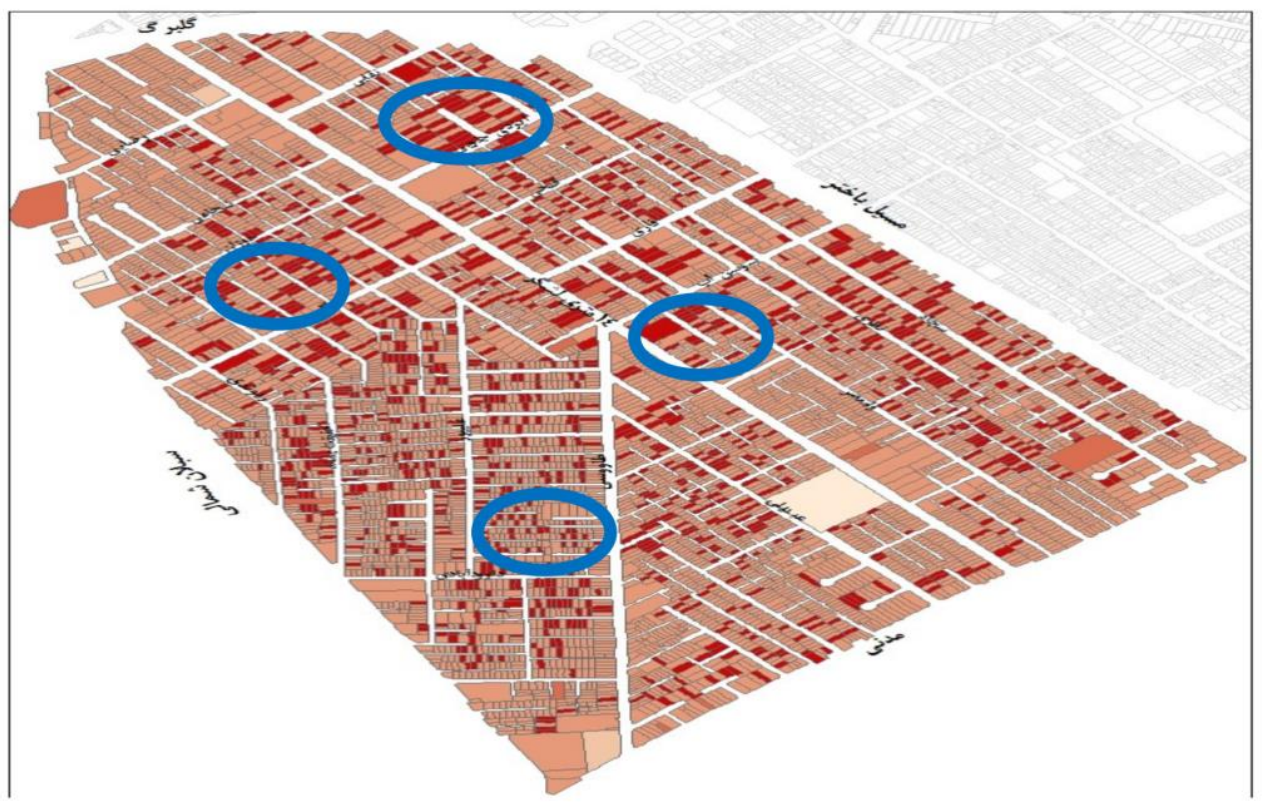

Fig. 5. Insecure neighborhood space.

\subsection{Socio-economic strategies}

Create identity environments that stimulate a sense of place by enhancing neighborhood services and enhancing the quality of the urban environment.

Balanced population loading at city level according to neighborhood environmental capabilities

Legalize statutory ownership by modifying segmentation and building congestion and encouraging landlords to renovate worn-out and abnormal tissue.

Promote the basic economy by encouraging tourism and catering services.

Encourage industries to use superior and non-polluting technologies to enhance the quality of the environment.

Promoting social capital by establishing education, higher education, and technicalvocational centers.

\subsection{Physical-spatial strategies}

Provide various applications in terms of level and per capita and how it is deployed in all required and extensible locations. 
Moving towards the use of a sustainable condominium pattern against the limitless residential land use.

Appropriate location of industrial, service and tourism uses and catering in and around the city according to the general principles of land use control and guidance in this type of land use.

Establish appropriate infrastructure such as major roads and communications, infrastructure and equipment, and the like, to accommodate industrial uses in the sectors considered on the basis of location.

Creating coherent service delivery axes and rules to address problems, residents on the one hand, and texture on the other.

Path modification in terms of role and cross-section and intersections geometrically.

Enhance urban environments by paying for complementary elements such as flooring, furniture and the like and existing abilities such as gardens.

Using existing natural topography to achieve the artifact topography pattern to establish visual relationships between different parts of the city.

\subsection{Participatory Development Strategies}

Implement participatory policies for the conservation of gardens such as land-use change and the possibility of establishing catering and tourism units within them with reduced discounts (subject to the prevention of cutting down even a single tree).

Shaping public-private partnerships for metropolitan projects

Involvement of civil society organizations and people in the administration of neighborhoods (strengthening councils).

\subsection{Development management strategies}

Strengthening and training the municipal staff to control and guide development within the framework of the Strategic Master Plan.

Establishing sustainable revenue sources for the municipality (tax and tax system and receiving utility costs).

Encourage municipal and private sector partnerships and owners to implement urban development plans.

Participating citizens in the administration of neighborhoods through the creation of councils.

Collaborate with other cities in the area to implement joint projects, especially on roads and the environment.

\section{Politics}

\subsection{Executive policies for the realization of development strategies}

One of the most important factors in the realization of development strategies in district 8 of Tehran, considering the type of ideas in the expression of development strategies in defining and delineating the proposed city boundary line on the one hand and reaching the boundaries formulated in the area and city-level service plan in different areas. Is. Considering the proposed zoning as well as the population of the city according to the plan, there does not seem to be much of a change in the legal framework but considering the future role of the city in the intended industry and services as well as the gardens issue and 
maximal effort in line. Their preservation and restoration and the way land are distributed throughout the city and their ownership has changed little in the area of the city.

\subsection{Subject Policies}

\subsubsection{City Development Plans General Policies}

Define a variety of thematic projects in the context of worn textures.

Increased permeability in compact urban textures.

Determining ownership, securing sustainable funding, and providing citizen participation in improvement and organization (planning, implementation, review, and review).

Adoption of macro policies and basic capabilities by people, officials and city managers.

Improving the quality of the residential environment by identifying identifiable elements.

Solutions Diverse spatial ideas and avoid identical patterns for different tissue types.

Organizing actions with the participation of people and officials.

The physical space of the subject (residential texture, urban texture, axes, etc.)

Beneficiaries (including potential actual residents) of the community and potential city residents.

Investors (including land and building investors at different local, regional and national levels).

Decision-makers and decision-makers (including decision-makers and decision-makers at various levels above).

Managers and executives, including decision-makers and executives.

Equipping financial and human resources (main development contribution) for urban development measures.

\subsubsection{Policy Policies}

Topical and case policies in Tehran District 8 are summarized as follows:

Organizing industries incompatible with the residential environment: As discussed in the existing land use section, the southern and eastern parts of the neighborhood are of industrial and workshop uses sometimes incompatible with the urban environment. The main policies for dealing with such uses can be stated in two cases. Integrating and establishing neighborhood-scale work and activity centers within the range of exhibit uses and sales units. Another policy is related to industrial and workshop uses, which can be arranged in the design of the Tehran metropolitan area with the thinkers of industrial centers around the neighborhood. The relocation of such land uses and the liberation of their lands for the purposes of residential and service uses by the design guidelines. Is.

Identifying Neighborhood Primary Core: Reclaiming Forgotten Primary Neighborhood Formation around Nizamabad is the most important approach to achieving lost neighborhood identity. Providing a suitable pattern in this area in the form of a detailed scale plan (in the form of a local plan), this center will revitalize the neighborhood identity.

Strengthening the Role and Position of the Neighborhood in the Urban Area: District 8 of Tehran One of the major areas of the city Is. The placement of educational and tourism zones in the city, as well as the industrial expanse on the eastern lands, is an example of this role. 


\section{Solutions and Suggestions to increase neighborhood security}

Based on the analysis of urban security in this neighborhood and based on urban planning experiences we can propose solutions to increase urban security in this neighborhood. The following table 4 presents the executive solutions to increase neighborhood security

Table 4. Solutions and Suggestions to create security in the Lashkar neighborhood.

\begin{tabular}{|l|l|}
\hline Criteria & \multicolumn{1}{c|}{ Solutions and Suggestions } \\
\hline \multirow{5}{*}{ Access control } & Neighborhood access is controlled from the main streets \\
& Traffic calming on local streets and alleys \\
& Locating trails in socially supervised places \\
Using sidewalks to define the boundaries of pedestrians & - Avoid unnecessary connection of other pavements to the main pavement \\
- Use landscape design to guide people on a safe path \\
Design a curb path so that it can be seen at least through one of the windows \\
or the front or back doors of the house \\
Territory
\end{tabular}

\section{Conclusion}

The proposed methodological approach to the analysis of problem situations in the city, and then the proposals for their elimination in urban development policies, summarizes the earlier studies on the topic of sustainable urban design security and generalizes them with a specific example of one of the developed regions of Iran. The material may be of interest to the urban planning community for making management decisions and real design. 


\section{References}

1. N.A. Samoylova, Yu.V. Alekseev, TECIS 2018 51(30), 780-785 (2018)

2. N.A. Samoylova, RAACS 1, 415-431 (2019)

3. A. Mottaeva, , E3S Web of Conferences, 110, 02166, (2019) doi.org/10.1051/e3sconf /201911002166

4. N.A. Samoylova, O.A. Zhirkov, Yu.V. Alekseev, APCSCE 456, 012088 (2018)

5. N.A. Samoylova, O.A. Zhirkov, NRU MGSU, 66-67 (2019)

6. Asayesh and Moshiri, Goms, 48-71 (2010)

7. A.T. Murray, I. McGuffog, J. S. Western, P. Mullins, British Journal of Criminology 41.2, 309-329 (2001)

8. R.H. Schneider, T. Kitchen, RTPI library series, Planning for crime prevention 3, 141176 (2002)

9. A.I. Randall, CRC Press, 405-427 (2013)

10. J. Jacobs, New York Random House, 134-169 (2013)

11. O. Newman, New York Macmillan, 66-91 (2007/1972)

12. T. Crowe, Boston Butterworth-Heinman, 310-328 (2013)

13. P.M. Cozens, Journal Planning Practice \& Research 26, 481-508 (2011)

14. M.B. Robinson, Advances in Criminological Theory 8 (2006) 